\title{
KEEFEKTIFAN PEMBELAJARAN KOOPERATIF TIPE STAD INTEGRASI TEORI BELAJAR VAN HIELE PADA MATERI GEOMETRI DI KELAS V SEKOLAH DASAR
}

\author{
Arie Anang Setyo \\ Pendidikan Matematika, Universitas Muhammadiyah Sorong \\ Email: arieanangsetyo.ums@gmail.com
}

\begin{abstract}
Abstrak, Penelitian ini bertujuan untuk mengidentifikasi evektivitas Pembelajaran kooperatif tipe STAD integrasi teori belajar Van hiele pada materi geometri di kelas V SD Inpres 109 Perumnas Kota Sorong. Penelitian ini menggunakan desain "One Group Pretest-postest Design" yang merupakan salah satu bentuk desain dari pre-eksperimental. Populasi dalam penelitian ini adalah peserta didik kelas V SD Inpres 109 Perumnas Kota Sorong yang berjumlah 120 orang yang tersebar dalam 3 kelas yaitu kelas VA, VB, dan VC. Pengambilan sampel pada penelitian ini menggunakan teknik simple random sampling, yaitu dengan mengundi ketiga kelas, dan yang terpilih menjadi sampel penelitian adalah kelas VA dengan jumlah siswa siswa adalah 37 orang. Intrumen yang digunakan adalah tes hasil belajar dan angket respon peserta didik. Hasil penelitian menunjukkan bahwa Penerapan model pembelajaran kooperatif tipe STAD integrasi teori belajar Van Hiele efektif untuk meningkatkan hasil belajar matematika materi geometri di kelas V SD Inpres 109 Perumnas Kota Sorong, dimana dapat dilihat pada rata-rata pretest yang hanya mencapai 10,49 meningkat pada saat posttest menjadi 71,30 dengan ketuntasan klasikal dari $0 \%$ menjadi $81,08 \%$ dan nilai Gain ternormalisasi n(N-gain) mencapai 0,68 dengan kategori sedang.

Kata Kunci : Koperatif Tipe STAD, Teori Belajar Van hiele, Geometri.
\end{abstract}




\section{PENDAHULUAN}

Peningkatan Sumber Daya Manusia (SDM) merupakan tolak ukur kemajuan pendidikan nasional. Banyak faktor yang mempengaruhi kemajuan pendidikan nasional diantaranya adalah sistem pendidikan nasional. Didalamnya terdapat peserta didik, tenaga kependidikan, pendidik, jalur pendidikan, jenis pendidikan dan satuan pendidikan.

Pembelajaran matematika memerlukan keterampilan dari seorang guru agar anak didik mudah memahami materi yang diberikan guru. Jika guru kurang menguasai strategi mengajar maka siswa akan sulit menerima materi pelajaran dengan sempurna. Guru dituntut untuk mengadakan inovasi dan berkreasi dalam melaksanakan pembelajaran, sehingga hasil belajar siswa memuaskan dan sesuai dengan tujuan pembelajaran yang diharapkan.

Sebagian besar guru masih menerapkan proses belajar mengajar matematika dimana siswa hanya melihat, dan mendengarkan, kemudian menyalin dan mengerjakan soal serta diakhir pembelajaran diberikan tugas rumah, dan kegiatan ini dilaksanakan secara terus menerus. Disadari atau tidak hampir semua guru disetiap jenjang pendidikan menggunakan metode seperti ini, Sehingga siswa merasa bosan dan konsep matematika yang seharusnya dikuasai siswa tidak dapat dimiliki oleh siswa.

Sekolah Dasar Inpres 109 Perumnas merupakan salah satu sekolah dasar yang berada di kota sorong dan termasuk sekolah unggulan dan faforit. Hal ini ditunjukkan bahwa sekolah tersebut mendapatkan akreditasi A, mendapatkan juara umum lomba kebersihan tingkat kota Sorong dua tahun berturut-turut ditahun 2013 dan 2014, termasuk sekolah adiwiyata tingkat propinsi papua barat, dan pada bulan desember 2015 mendapatkan piagam sekolah adiwiyata tingkat nasional.

Sebagian besar siswa kelas V SD Inpres 109 perumnas merasa bahwa matematika tidak menyenangkan bahkan sangat membosankan, apalagi ketika pembelajaran matematika diajarkan pada jam-jam akhir sekolah. hal ini menyebabkan pembelajaran matematika kurang mendapat perhatian para siswa, dan tidak sedikit siswa yang beranggapan matematika hanyalah ilmu yang berkaitan dengan angka-angka dan tidak berguna. Hal ini menyebabkan konsep matematika yang dimiliki siswa sangat rendah sehingga pada ujian semester ganjil tahun 
pelajaran 2015/2016, rata-rata nilai siswa hanya 63 dan dari 48 siswa, masih terdapat 20 siwa yang mendapat nilai kurang dari 65. Kondisi ini menunjukkan bahwa ketuntasan belajar siswa belum mencapai ketuntasan klasikal yaitu $75 \%$ siswa sudah mencapai kriteria ketuntasan minimal (KKM) .

Serangkaian uraian di atas sudah jelas menggambarkan bahwa permasalahan yang terjadi dan dihadapi guru dan para siswa yang menyebabkan penguasaan konsep matematika hasil dari pelaksanaan pembelajaran dan nilai matematika rendah adalah penggunaan model, metode dan teknik serta media pembelajaran yang tidak sesuai dengan karakteristik peserta didik,.

Penelitian ini dilakukan untuk mengatasi masalah di atas dengan penerapan model pembelajaran kooperatif integrasi teori belajar Van Hiele untuk materi geometri. Peneliti menggunakan model pembelajaran tersebut di atas, karena guru kelas $\mathrm{V}$ tempat dilaksankan penelitian ini diperoleh data bahwa guru tersebut lebih dominan menggunakan pembelajaran konvesional dan ceramah pada setiap melaksanakan pembelajaran, materi sifat-sifat bagun datar dan bangun ruang menjadi pilihan untuk diteliti karena materi ini lebih kompleks dan baru didapatkan dikelas $\mathrm{V}$.

Dalam penelitian ini, peneliti menerapkan pembelajaran kooperatif tipe Student Team Achievement Division (STAD), karena tipe STAD yang dikembangkan oleh Robert Slavin dan rekan-rekan sejawatnya di Jhon Hopkins Univercity merupakan pendekatan pembelajaran kooperatif yang paling sederhana dan paling mudah dipahami (Arends, 2008: 13). Disamping itu model pembelajaran kooperatif tipe STAD tidak hanya unggul dalam membantu siswa memahami konsep-konsep sulit, tetapi juga sangat berguna untuk menumbuhkan interaksi antar guru dan siswa, meningkatkan kerjasama, kreativitas berpikir kritis serta ada kemauan membantu teman (Ibrahim, 2000). Selaras dengan hal ini, Slavin (2008:143) juga mengemukakan bahwa "STAD merupakan salah satu metode (tipe, pen) pembelajaran kooperatif yang paling sederhana dan merupakan tipe yang paling baik untuk permulaan bagi guru yang baru menggunakan pendekatan (tipe, pen) kooperatif'. 
METODE

Desain penelitian yang digunakan dalam penelitian ini adalah "One Group Pretest-postest Design" yang merupakan salah satu bentuk desain dari preeksperimental (Lestari \& Yudhanegara, 2015: 122).

Intrumen dalam penelitian ini adalah tes hasil belajar dan angket respons peserta didik. Analisi data mengunakan teknik analisis statistic deskriptif dan analisis statistic infrensial. Dengan bantuan SPSS For windows 24.
Berdasarkan hasil pengolahan data, maka penelitian ini dapat dijelaskan sebagai berikut.

\section{Hasil Statistik deskriptif}

Berdasarkan kriteria ketuntasan minimal (KKM) yang berlaku di SD Inpres 109 Perumnas yaitu 65, maka tingkat pencapaian ketuntasan hasil belajar matematika peserta didik secara klasikal pada kelas yang diajar dengan menggunakan model pembelajaran kooperatif tipe STAD dengan integ teori Van Hiele, dapat dilihat pada tabel 1

Tabel 1. Distribusi ketuntasan hasil

belajar peserta

Frekuensi

Peresentase

Interval Nilai Kategori

\begin{tabular}{lccccc} 
& & Pretest & Posttest & Pretest & Posttest \\
\hline $65,00-100,00$ & Tuntas & 0 & 30 & $0 \%$ & $81,08 \%$ \\
\hline $0,00-64,99$ & Tidak Tuntas & 37 & 7 & $100 \%$ & $18,92 \%$ \\
\hline Jumlah & 37 & 37 & $100 \%$ & $100 \%$ \\
\hline
\end{tabular}

HASIL DAN PEMBAHASAN

Tabel 1. di atas menunjukan bahwa hasil pretest peserta didik tidak ada yang 
mencapai ketuntasan belajar dan hasil belajar setelah posttest peserta didik menunjukkan bahwa yang tuntas secara klasikal sebesar 81,08 \% dan telah memenuhi ketuntasan klasikal yang ditetapkan di SD Inpres 109 Perumnas yaitu $75 \%$.

Selain data ketuntasan hasil belajar secara klasikal, data yang di olah secara statistik deskriptif adalah data hasil perhitungan nilai gain. Pada tabel 4.5 akan ditampilkan data nilai gain ternormalisai dan beberapa perhitungan lainya.

\section{Respons peserta didik}

Tabel 2. Hasil respons peserta didik $(\mathrm{n}=$ 37, nilai ideal 4)

\begin{tabular}{|c|c|c|}
\hline Indikator & Rata-rata & Kategori \\
\hline \multirow{2}{*}{1.} & \multirow{2}{*}{3,30} & Cenderung \\
\hline & & Positif \\
\hline \multirow{2}{*}{2.} & \multirow{2}{*}{3,30} & Cenderung \\
\hline & & Positif \\
\hline \multirow{2}{*}{3.} & \multirow{2}{*}{3,43} & Cenderung \\
\hline & & Positif \\
\hline \multirow{2}{*}{4.} & \multirow{2}{*}{3,35} & Cenderung \\
\hline & & Positif \\
\hline \multirow{2}{*}{5.} & \multirow{2}{*}{3,51} & Cenderung \\
\hline & & Positif \\
\hline \multirow{2}{*}{6.} & \multirow{2}{*}{3,41} & Cenderung \\
\hline & & Positif \\
\hline
\end{tabular}

\begin{tabular}{|c|c|c|}
\hline 7. & 3,22 & $\begin{array}{c}\text { Cenderung } \\
\text { Positif }\end{array}$ \\
\hline 8. & 3,38 & $\begin{array}{c}\text { Cenderung } \\
\text { Positif }\end{array}$ \\
\hline $\begin{array}{l}\text { Rata-rata } \\
\text { total }\end{array}$ & 3,36 & $\begin{array}{c}\text { Cenderung } \\
\text { Positif }\end{array}$ \\
\hline
\end{tabular}

Berdasarkan tabel 2. rata-rata respons peserta didik setiap indikator berada pada kategori cenderung positif. Berdasarkan hasil rata-rata kedelapan indikator dapat diperoleh rata-rata total 3,36 dan berada pada kategori cenderung positif. Hal dapat disimpulkan bahwa respons peserta didik kelas V SD Inpres 109 Perumnas secara klasikal cenderung positif terhadap penerapan model pembelajaran kooperatif tipe STAD dengan memenfaatkan teori Van Hiele pada materi sifat-sifat bangun datar dikelas V SD Inpres 109 Perumnas.

\section{Hasil Analisis Statistik Inferensial}

Hasil pengujian normalitas

Hasil uji normalitas dalam penelitian ini adalah uji statistik dari data nilai posttest dan nilai $\mathrm{N}$-gain yang di uji menggunakan SPSS 24. Hasil pengujian tersebut dapat dilihat pada tabel 2 .. 
Sesuai data yang ditampilkan pada tabel 3, terlihat bahwa pada uji normalitas dengan statistik Kolmogorov-smirnov pada nilai hasil posttest menunjukkan bahwa nilai statistiknya berturut-turut 0,143 dengan "P Value (sig)" sebesar 0,06 Karena "P Value (sig)" lebih besar dari 0,05 maka dapat disimpulkan bahwa data hasil nilai posttest setelah pelaksanaan model pembelajaran kooperatif tipe STAD dengan integrasi teori Van Hiele berada pada asumsi normal. Pada tabel 2. juga menghasilkan nilai statistik 0,14 dengan "P value (sig)" 0,07. Nilai "P value yang lebih besar dari 0,05 menunjukkan bahwa nilai N-gain berasal pada populasi yang berdistribusi normal. Berdasarkan uraian di atas dapat disimpulkan bahwa nilai posttest dan nilai gain ternormalisasi yang diperoleh setelah penerapan model

Berdasarkan tabel 3.. didapat data bahwa penelitian ini dilakukan pada sampel yang berdistribusi normal. Selanjutnya data hasil posttest dan nilai

Tabel 3. Hasil Uji Normalitas Posttest dan N-gain

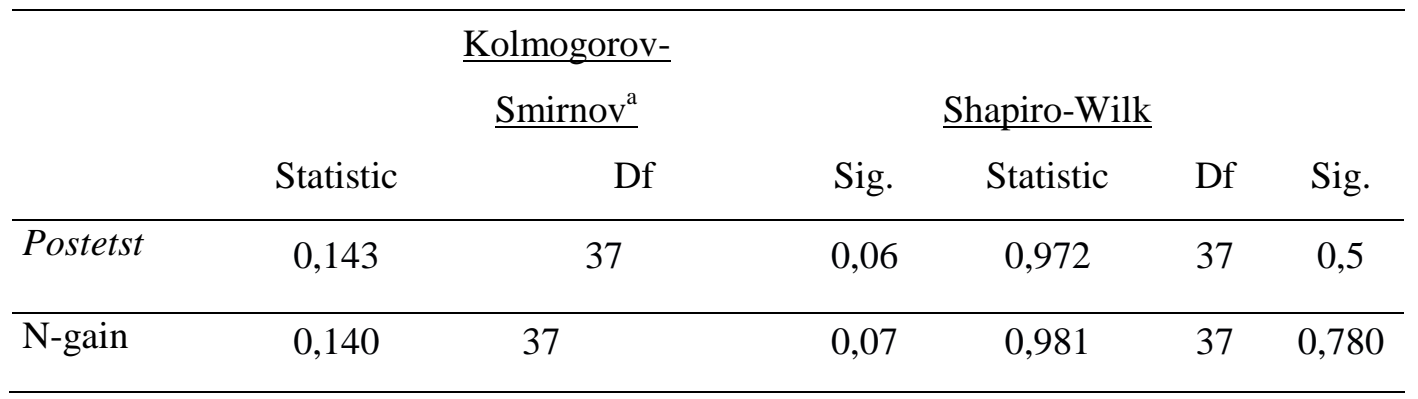

\section{One-Sample Test}

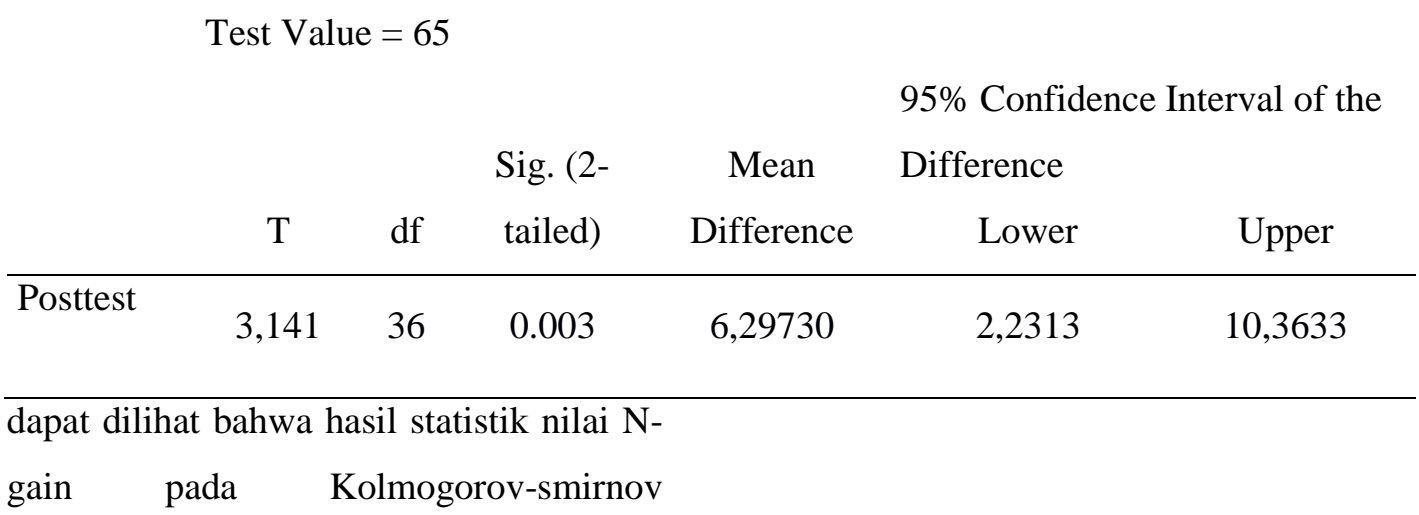


$\mathrm{N}$-gain tersebut dapat digunakan untuk menguji hipotesis penelitian.

Hasil uji hipotesis

a. Hasil penujian hipotesis minor 1

Hipotesis minor 1, adalah Rata-rata hasil belajar peserta didik setelah pelaksanaan proses pembelajaran dengan model kooperatif tipe STAD dengan integrasi teori Van Hiele, mencapai KKM SD Inpres 109 Perumnas yaitu 65, Untuk keperluan pengujian secara statistik, maka dirumuskan hipotesis kerja sebagai berikut:

Berdasarkan tabel 3. dapat dilihat bahwa nilai t hitung adalah 3,141 dengan "P value (sig. (2-tailed))" sebesar 0,003 hal ini menunjukkan bahwa "P value" lebih kecil dari taraf signifikansi 0,05. Dengan demikian dapat dikatakan bahwa $\mathrm{H}_{0}$ pada hipotesis minor 1 ditolak sehingga hipotesis alternatif atau $\mathrm{H}_{1}$ diterima. Sehingga dapat disimpulkan bahwa berdasarkan hasil uji hipotesis minor 1 menunjukkan bahwa secara infrensial rata-rata hasil belajar peserta didik setelah pelaksanaan pembelajaran dengan model kooperatif tipe STAD dengan integrasi teori Van Hiele pada kelas $\mathrm{v}$ SD Inpres 109 Perumnas mencapai KKM 65.

b. Hasil pengujian hipotesis minor 2
Hipotesis minor yang kedua adalah $75 \%$ peserta didik setelah pelaksanaan proses pembelajaran dengan model kooperatif tipe STAD dengan integrasi teori Van Hiele tuntas secara klasikal berdasarkan kriteria ketuntasan minimal (KKM) SD Inpres 109 Perumnas, Untuk keperluan pengujian secara statistik, maka dirumuskan hipotesis kerja sebagai berikut:

$$
\mathrm{H}_{0}: \mu_{1} \leq 74,9 \% \text { Lawan } \mathrm{H}_{1}: \mu_{1}>74,9
$$

$\%$

Keterangan : $\mu_{1}=$ parameter skor rata-rata hasil belajar klasikal peserta didik

Untuk menguji hipotesis tersebut digunakan uji $\mathrm{Z}$ pihak kanan. Dengan rumus :

$Z$ hitung $=\frac{\frac{x}{n}-\pi_{0}}{\sqrt{\frac{\pi_{0}\left(1-\pi_{0}\right)}{n}}}$

Keterangan :

$\mathrm{x}=$ Banyak data yang mencapai $\mathrm{KKM}=$ 30

$\mathrm{n}=$ Banyak data $=37$

$\pi_{0}=$ proporsi pada hipotesis $=74,9 \%=$ 0,749

$$
\begin{array}{r}
Z \text { hitung }=\frac{\frac{30}{37}-0,749}{\sqrt{\frac{0,74,9(1-0,749)}{37}}} \\
=\frac{0,061}{0,071}=0,867
\end{array}
$$


$\mathrm{Z}$ tabel $=1,645$

Maka Z Hitung $<$ Z tabel sehingga tidak cukup bukti untuk metolak Ho.

Berdasarkan perhitungan di atas dapat dilihat bahwa nilai $\mathrm{Z}$ hitung $<\mathrm{Z}$ tabel. Hal ini dapat katakan bahwa $\mathrm{H}_{0}$ diterima sehingga $\mathrm{H}_{1}$ tolak. Sehingga dapat disimpulkan bahwa ketuntasan klasikal peserta didik pada saat posttest setelah pelaksanaan proses pembelajaran dengan model kooperatif tipe STAD dengan integrasi teori Van Hiele secara infrensial tidak signifikan tuntas secara klasikal.

c. Hasil pengujian Hipotesis minor 3

Tabel 5. Hasil pengujian N-Gain gain ternormalisasi peserta didik yang diajar dengan pembelajaran kooperatif tipe STAD dengan integrasi teori Van Hiele lebih besar dari 0,29.

Selaras dengan uraian di atas dapat disimpulkan ketiga $\mathrm{H}_{0}$ minor ditolak sehingga ketiga $\mathrm{H}_{1}$ minor diterima maka dapat dikatakan bahwa $\mathrm{H}_{0}$ mayor juga ditolak dan menirima $\mathrm{H}_{1}$ mayor, sehingga disimpulkan bahwa Model pembelajaran Koperatif tipe STAD dengan integrasi teori bejajar Van Hiele efektif diterapkan pada materi sifat-sifat bangun datar di kelas V SD Inpres 109 Perumnas Kota Sorong .

Test Value $=0.29$

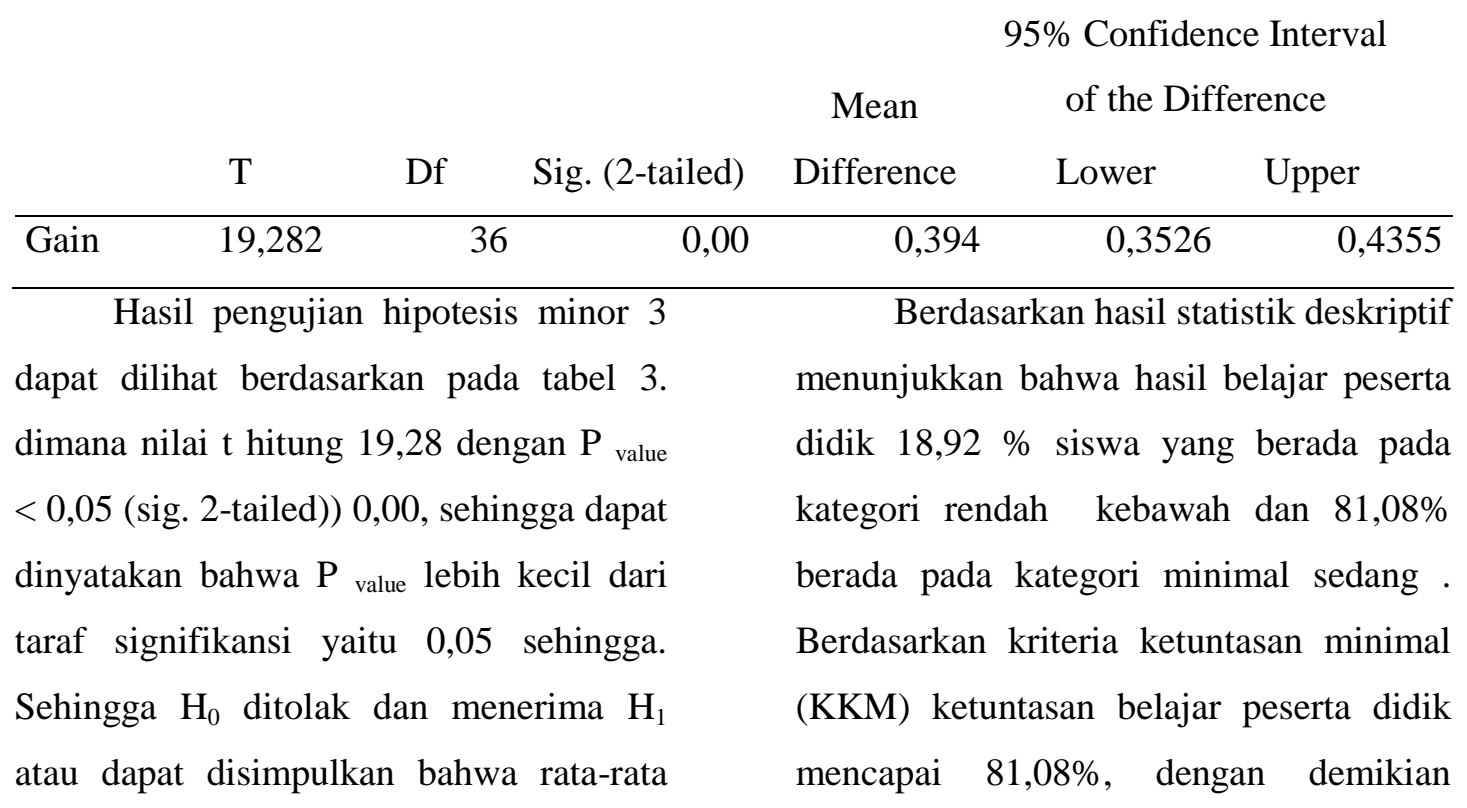


tingkat pencapaian ketuntasan hasil belajar matematika peserta didik secara klasikal pada kelas yang diajar dengan menggunakan model pembelajaran kooperatif tipe STAD dengan integrasi teori Van Hiele meningkat, dari sebelumnya dimana pada saat sebelelum pelaksanaan pembelajaran tidak terdapat seorangpun nilai pretest mencapai KKM.

Berdasarkan analisis statistik infrensial dapat dijelaskan bahwa hasil analisis infrensial hipotesis minor 1 yang berkaitan dengan kriteria ketuntasan minimal (KKM) dan hipotesis minor 3 yang berkaitan dengan ketercapaian standar nilai $\mathrm{N}$-gain sudah signifikan, namun pada hipotesis minor 2 yang berhubungan dengan ketuntasan klasikal setelah di uji berdasarkan uji proporsi masih menunjukkan bahwa ketuntasan klasikal belum menunjukkan taraf signifikan. Hal ini terjadi karena penerapan model pembelajaran kooperatif tipe STAD dengan integrasi teori Van Hiele baru diterapkan pada kelas tersebut. Namun jika dipandang dari kriteria keefektifan, dapat disimpulkan bahwa model pembelajaran kooperatif tipe STAD dengan integrasi teori Van Hiele efektif diterapkan pada kelas V SD Inpres 109 Perumnas kota Sorong Materi geometri.
Berdasarkan uraian di atas dapat disimpulkan bahwa hasil belajar peserta didik pada kelas $\mathrm{V}$ materi sifat-sifat bangun datar setelah pelaksanaan model pembelajaran kooperatif tipe STAD dengan integrasi teori Van Hiele menjadi lebih baik dari pada sebelumnya. Hal ini dapat dilihat dari rata-rata hasil belajar peserta didik sudah mencapai 71,30 dengan kategori sedang dan ketuntasan klasikal sudah mencapai $81,08 \%$ sudah memenuhi ketuntasan klasikal minimal dengan nilai $\mathrm{N}$-gain sudah mencapai 0,67 dengan kategori sedang, berdasarkan kriteria keefektifan, maka hasil belajar berada pada kategori efektif.

Sejalan dengan hasil pembahasan di atas maka dapat dikatakan bahwa pelaksanaan pembelajaran melalui penerapan model pembelajaran kooperatif tipe STAD dengan integrasi teori Van Hiele efektif diterapkan untuk meningkatkan aktivitas dan hasil belajar peserta didik. Hal ini selaras dengan pendapat Arends (2008: 5) mengemukakan bahwa "Model cooperative learning dikembangkan untuk mencapai paling sedikit tiga tujuan penting yaitu Prestasi akademis, toleransi dan penerimaan terhadap keanekaragaman, dan pengembangan 
ketrampilan sosial". Slavin (2008: 33) juga mengemukakan bahwa "Tujuan yang paling penting dari pembelajaran koopertif adalah untuk memberikan para siswa pengetahuan, konsep, kemampuan, dan pemahaman yang mereka butuhkan supaya bisa menjadi anggota masyarakat yang bahagia dan memberikan kontribusi”. Ibrahim dkk (2005: 7) juga mengatakan menambahkan bahwa “ Model pembelajaran kooperatif dikembangkan untuk mencapai setidaktidaknya tiga tujuan pembelajaran penting, yaitu prestasi belajar akademik, penerimaan terhadap keragaman, dan pengembangan ketrampilan sosial".

Terdapat beberapa kelemahan penggunaan model pembelajaran kooperatif tipe STAD yaitu pada saat di awal-awal pelaksanaan pembelajaran pengkondisian siswa dalam kelompok dan kegiatan pembelajaran kurang maksimal, sehingga sebelum pelaksanaan pembelajaran perlu dilakukan pra pembelajaran dan pengenalan (simulasi) model pembelajaran kooperatif tipe STAD agar pelaksanaan pembelajaran lebih maksimal.

\section{SIMPULAN DAN SARAN}

\section{Simpulan}

Bedasarkan hasil penelitian dan pembahsan dapat disimpulkan bahwa Kesimpulan yang dapat ditarik pada penelitian ini adalah sebagai berikut: Penerapan model pembelajaran kooperatif tipe STAD dengan integrasi teori belajar Van Hiele efektif untuk meningkatkan hasil belajar matematika materi geometri di kelas V SD Inpres 109 Perumnas Kota Sorong, Terdapat peningkatan hasil belajar matematika peserta didik setelah penerapan model pembelajaran kooperatif tipe STAD dengan integrasi teori Van Hiele dimana nilai rata-rata pretest 10 dengan peningkatan hasil saat posttest mencapai 71,30 dengan ketuntasan klasikal 81,08\%

\section{Saran}

Saran peneliti bagi guru kelas V SD Inpres 109 Perumnas Kota Sorong dan juga guru kelas V disekolah lain baik di kota sorong ataupun diseluruh Indonesia, kiranya pembelajaran kooperatif tipe STAD integrasi teori belajar Van Hiele dapat dipilih menjadi salah satu strategi yang dapat digunakan untuk menanamkan 
konsep dan meningkatkan hasil belajar siswa materi Geometri.

\section{DAFTAR RUJUKAN}

Abdussakir.2010.Pembelajaran Geometri Sesuai Teori Van Hiele.Artikel dimuat dalam El-Hikmah: Jurnal Kependidikan dan Keagaman, Vol VII Nomor 2.

Alwi, Hasan. 2007. Kamus Besar Bahasa Indonesia. Jakarta: Balai Pustaka

Anderson,L.W， Krathwohl， D.R.2014. Kerangka Landasan untuk Pembelajaran, Pengajaran, dan Asesmen Revisi Taksonomi Pendidikan Bloom. Diterjemahkan dari A Taxonomy for Learning, Teaching, and Assesing : A Revision Of Blooms Taxonomy of Educational Objektives Abridged Edition , 1 st, Edition penerjemah Agung prihantoro. Yogyakarta Pustaka Belajar

Ardin. 2012. Efektifitas Pembelajaran Matematika Realistik Setting Kooperatif NHT dapat Menjadi Solusi dari Permasalahan dalam Pembelajaran Matematika di Kelas X SMAN 1 Kulisusu. Tesis. Tidak diterbitkan. Makassar: Program Pasca Sarjana Universitas Negeri Makassar.

Arends, Richard,I.2008. Learning to Teach Belajar untuk Mengajar. Edisi Tujuh. Buku Dua. Yogyakarta: Pustaka belajar

Asmawati. 2010. Komparasi KEEFEKTIFAN Pembelajaran Matematika kooperatif tipe STAD dan tipe NHT dalam pembelajaran matriks pada siswa kelas X SMK Negeri 1 Palangga Gowa. Tesis . tidak diterbitan. Makassar: Program Pasca Sarjana Universitas Negeri Makassar.

Dasna, I, Wayan.dkk. Materi Pokok Desain dan Model Pembelajaran Inovasi dan Interaktif, 19/MPDR5203/3sks. Tangerang Selatan: Universitas Terbuka.

DePorter,dkk.2004. Quantum Teaching. Mempraktikkan Quantum Learning di Ruang-ruang Kelas.diterjemahkan dari. Qantum Teaching : Orchestrating Student Succes: penerjemah Ary Nilandari.Bandung: Kaifa

Glower. David.2007. Buku Referensi Apa dan Bagaimana Matematika? A-Z. Volume 1-3.Bandung: Grafindo Media Pratama.

Gunarto,Dedi,Sugiono.2009.Matematika SD/MI Kelas V. Depdiknas: Jakarta

Hamalik, Oemar. 2012.Kurikulum dan Pembelajaran. Jakarta: Bumi Aksara

Hambali, Julius, Dkk. 1992. Materi Pokok Pendidikan Matematika 1.Universitas Terbuka: DepdikbudJakarta

Hamiyah, Nur. 2011. Soal dan Pembahasan Olimpiade Tingkat Internasional untuk SMP dan MTs Ed.Bilingual (Indonesia-Inggris) . Jakarta Cerdas Pustaka Publisher

Hamzah, M.Ali, Muhlisrarini.2014. Perencanaan dan Strategi Pembelajaran Matematika. Jakarta: Rajawali Pers 
Haryono, Didi. 2014. Filsafat Matematika. Bandung: Alfabeta

Https://id.wikipedia.org/wiki/Layanglayang (geometri)

Ibrahim, Muslimin, dkk. 2000. Pembelajaran Kooperatif. Surabaya: UNESA Press

Ibrahim, Muslimin, dkk.2005. Pembelajaran Kooperatif. Surabaya:Pusat Sains dan Matematika Sekolah Universitas Negeri Malang.

Inganah, Siti, dkk.2005. Belajar dan Pembelajaran. Malang: Universitas Muhammadiyah Malang.

Ismail.1998.Kapita Selekta Pembelajaran Matematika. Universitas Terbuka

Ilyas, B. \& Tiro, M. A. 2007. Statistika Terapan untuk Ilmu Ekonomi dan Ilmu Sosial Edisi Kedua. Makassar: Andira Publisher

Johartini, P. 2010. Keefektifan Penerapan Srategi Kognitif dalam Pembelajaran Matematika di SMK Negeri 2 Pare pare. Tesis. Tidak diterbitkan. Makassar: Program Pasca Sarjana Universitas Negeri Makassar.

Khafid, M. 2007.Pelajaran Matematika Kelas VB. Jakarta: Erlangga.

http://kbbi.web.id. Kamus Besar Bahasa Indonesia Online.

Lie, Anita. Cooperative Learning Mempraktikkan Cooperative Learning di Ruang-runag Kelas. Jakarta: Pt Grasindo
Lestari, E.K., Yudhanegara,M.R. 2015.Penelitian Pendidikan Matematika (Panduan Praktis menyusun Skripsi, Tesis, dan Karya Ilmiah dengan Pendekatan Kuantitatif, Kualitatif, dan Kombinasi disertai dengan Model pembelajaran dan Kemampuan Matematis. Bandung: Rafika Aditama.

Marini, Arita.2015. Geometri dan Pengukuran. Bandung: PT Remaja Rosdakarya.

Muchlisoh, dkk.1992. Materi Pokok Pendidikan Bahasa Indonesia 3 PPDG\#\$\#)/3SKS Modul 1-9. Jakarta: Universitas Terbuka,Depdikbud.

Muhsetyo, Gatot. 2007. Materi Pokok Pembelajaran Matematika SD:19/PDGK4406/3 SKS. Jakarta: Universitas Terbuka.

Peraturan Pemerintah Nomer 19 tahun 2005

Peraturan Menteri Pendidikan Nasional RI. Nomer 41 Tahun 2007

Peraturan Menteri Pendidikan Nasional RI. Nomer 22 Tahun 2006

Purwanto, 2009. Evaluasi Hasil Belajar. Yogyakarta: Pustaka Pelajar

Redhana, I Wayan.2010. Pengaruh Model Pembelajaran Berbasis Peta Argument terhadap ketrampilan Berpikir Kritis Siswa Pada Topic Laju Reaksi. Jurnal pendidikan dan pengajaran, 43(17),141-148

Sani, A. Ridwan. 2004. Pembelajaran saintifik untuk Implementasi 
Kurikulum 2013. Jakarta: Bumi Aksara.

Sanjaya Wina. 2007. Strategi Pembelajaran Berorientasi

Standar Proses Pendidikan. Edisi pertama, cetakan ketiga.Bandung: San Grafika.

Sanjaya Wina. 2007. Strategi Pembelajaran Berorientasi Standar Proses Pendidikan. Edisi pertama, Jakarta: Kencana Prenadamedia Group.

Sardiman. 2010. Interaksi dan Motivasi Belajar Mengajar. Jakarta: PT RajaGravindo Persada

Slavin, E, Robert, . 2008. Cooperatif Learning Teori, Riset dan Praktik. Bandung: Nusa Indah.

Soenarjo,RJ.2008.Matematika 5:Untuk SD/MI Kelas 5. Jakarta: Depdiknas.

Sudjana, Nana. 2013. Penilaian Hasil dan Proses Belajar Mengajar. Cetakan ketujuhbelas. Bandung: PT Remaja Rosdakara.

Sudjana, Nana. 2009. Penilaian Hasil Proses Belajar Mengajar. Bandung: PT Remaja Rosdakarya

Sugiono.2009. Metode Penelitian Pendekatan Kuantitatif , kualitatif dan $R \& D$. Bandung: Alfabeta

Suherman, Erman,dkk.2003. Strategi Pembelajaran Matematika Kontemporer.Bandung: Jurusan Pendidikan Matematika Fakultas Pendidikan dan Ilmu Pengetahuan Alam Universitas Pendidikan Indonesia
Sundayana, Rostina. 2013. Media Pembelajaran Matematika. Bandung: Alfabeta

Suyono dan Hariyanto. 2015. Belajar dan Pembelajran Teori dan Konsep Dasar. Bndung: Rosda.

Syam, Suhaemi. 2010. Keefektifan Strategi Generatif dengan Setting Kooperatif dalam Pembelajaran Matematika di Kelas X MAN 3 Makassar. Tesis. Tidak diterbitkan. Makassar: Program Pasca Sarjana Universitas Negeri Makassar.

Tiro, M, A. 2011. Penelitian: Skripsi, Tesis, dan Disertasi. Makassar: Andira Publisher.

Thobroni.2015. Belajar dan Pembelajaran Teori dan Praktek. Yogyakarta: Arruzz Media.

Undang-undang Replublik Indonesia No. 20 Tahun 2003 Tentang Sistem Pendidikan Nasional.

Uno, Hamzah, B. 2015. Teori Motivasi dan Pengukurannya Analisis di Bidang Pendidikan. Ed.1, Cet 12. Jakarta : Bumi aksara

Yusuf, A, Muri. 2015. Aseesmen dan Evaluasi pendidikan : Pilar Penyedia Informasi dan Kegiatan Pengendalaian Mutu Pendidikan .Prenadamedia Group: Jakarta 